\title{
Meaning, Meaningfulness, and Tensions in Artistic Work
}

\author{
Significado, Sentido e Tensões no Trabalho Artístico
}

\author{
» Pedro F. BENDASSOLLI ${ }^{1}$ (Universidade Federal do Rio Grande do Norte, Brasil) \\ "Jairo Eduardo BORGES-ANDRADE² (Universidade de Brasília, Brasil)
}

\section{Abstract}

Research about the meaning of work faces theoretical and practical challenges, such as empirically distinguishing between the meaning and meaningfulness of work. This study aims to explore the similarities and distinctions between the two concepts and how these reflect on the perception of tensions in the performance of one's professional activities. The study is based on in-depth interviews with 26 individuals working in creative industries in the state of São Paulo, Brazil. We analyzed the data through thematic categorization. We found that meaningfulness in artistic work is related, for example, to the social impacts of this form of activity. For the meaning of work, three central representations emerged: work as flow, as creation, and as a calling. Finally, related tensions emerged, such as those arising from the interconnection of art and business.

Keywords:

meaning of work; significance in work; representations of work; artistic work; professional artist.

\section{Resumo}

Pesquisas sobre significado do trabalho enfrentam desafios teóricos e práticos, como a diferenciação empírica entre significado do e sentido no trabalho. Objetiva-se explorar as complementaridades e diferenças entre ambos e seus reflexos na percepção de tensões no exercício da atividade profissional. Baseia-se em entrevistas em profundidade com 26 profissionais atuando em setores das indústrias criativas no Estado de São Paulo, Brasil. Os dados foram analisados por meio de categorização temática. Encontrou-se que o sentido no trabalho artístico está relacionado, por exemplo, aos impactos sociais desse tipo de atividade. Quanto ao significado do trabalho, três representações foram identificadas: o trabalho como fluxo, criação e como vocação. Finalmente, discutem-se as tensões relacionadas a esse trabalho, como a tensão entre arte e negócio.

Palavras-chave:

significado do trabalho; sentido no trabalho; representações do trabalho; trabalho artístico; artista profissional.

\section{Resumen Investigaciones sobre el significado del trabajo enfrentan desafíos teóricos y prácticos, como la} diferenciación empírica entre el significado y el sentido del trabajo. El objetivo de este estudio es explorar las complementariedades y las diferencias entre ambos y sus reflejos en la percepción de las tensiones en el ejercicio de la actividad profesional. Se sustenta en entrevistas en profundidad con 26 profesionales que actúan en los sectores de las industrias creativas en el Estado de São Paulo, Brasil. Los datos fueron analizados por medio de categorización temática. Se encontró que el sentido en el trabajo artístico está relacionado, por ejemplo, con el impacto social de este tipo de actividad. Cuanto al significado del trabajo, tres representaciones fueron identificadas: el trabajo como flujo, como creación y como vocación. Finalmente, se discuten las tensiones relacionadas con este tipo de trabajo, como la tensión entre el arte y los negocios.

Palabras-clave:

significado de trabajo; sentido de trabajo; representaciones de trabajo; trabajo artístico; artista profesional.

1 Departamento de Psicologia. Av. Salgado Filho, s/n - Cidade Universitária. 59072-970 - Natal - RN - Brasil. E-mail: pbendassolli@ gmail.com.

2 Departamento de Psicologia Social e do Trabalho. Instituto de Psicologia, ICC Sul. Campus Universitário Darcy Ribeiro. 70910-900 Brasília - DF - Brasil. E-mail: jairo.borges@gmail.com. 
$\mathrm{W}$ That makes work meaningful? For decades, this question has been the target of investigations in psychology, particularly in the literature on the meaning of work (Meaning of Work International Research Team [MOW], 1987). However, as in any other scientific field, theoretical questions remain open for discussion. One of these concerns the possible similarities and distinctions between the meaning and meaningfulness of work. In the international literature, Rosso, Dekas and Wrzesniewski (2010) explored this issue. These authors argued that the perception of meaning does not always correspond to the experience of meaningfulness, which led them to problematize the relationship between the meaning and meaningfulness of work. The former comprises the knowledge, representations, and cognitions that we form about our work, while the latter includes the characteristics of both the work and the people involved that are associated with the identification or sense of meaningfulness - defined in terms such as direction, purpose, and consistency between self and work. Similar theoretical discussions can also be found in the work of Brazilian authors (e.g., Tolfo, Coutinho, Baasch, \& Cugnier, 2011).

In this context, this article aims to investigate the differences and similarities between the meaning and meaningfulness of work, both empirically and in explorative fashion. To this end, the article analyzes data from a sector of contemporary economics that is little explored by organizational and work psychology research, namely, the arts. More specifically, it studies the work of the artist, touted as rich in possibilities of meaningfulness, since it allows greater contact with the expressive features of work, as opposed to the instrumentals (Menger, 2002, 2009). We seek to investigate the meaning and significance of artistic activity, as well as the possibility of tensions arising from the perception of discrepancies between the two. Our choice of discussing such tensions is based on the premise that they can serve as a useful starting point for thinking about the interactions between meaning and meaningfulness at work.

\section{THEORETICAL FRAMEWORK}

First, we describe some of the traditional topics of research on the meaning of work. Then we focus on the characteristics of the theoretical perspective we adopt. Considering the diversity and controversies concerning boundaries and conceptual overlaps in the literature on the meaning of work, at least in the Brazilian context, we will discuss two current and broad branches of this literature: one related to the meaning of work, and the other related to its meaningfulness. Besides the reasons already mentioned by Rosso et al. (2010), other authors also highlight the plausibility and fertility of this distinction (e.g., Lips-Wiersma \& Morris, 2009; Pratt \& Ashforth, 2003).

\section{The Meaning of Work}

The axis of the meaning of work brings together studies whose purpose is to determine what this meaning is - that is, the cognitive representations and cognitive maps that organize one's experience with work. At least six major research topics have been inspired by this concept.

The first topic, dating back to the 1950s and perhaps the inauguration of this field, concerns involvement in and the projection and centrality of work (Dubin, 1956; Gonzales \& Vilela, 2005; Harpaz \& Fu, 1997; Kanungo, 1982; MOW, 1987; Salanova, Gracia, \& Peiró, 1996; Tomás, 1998). This line of research seeks to determine the importance of work compared to other spheres of life. The second topic is work orientation (Kaplan \& Tausky, 1974; MOW, 1987; Wrzesniewski, McCauley, Rozin, \& Schwartz, 1997), with researchers investigating the kind of orientation, whether instrumental or expressive, that people have towards their work - for example, as a job, career, or vocation.

The third topic includes beliefs and values related to work (Borges, 1997; Buchholz, 1977; Ros, Schwartz, \& Surkiss, 1999; Super \& Sverko, 1995). Among other things, this research focuses on identifying the goals that individuals seek to achieve through their work (values) and on determining what people understand by work, that is, which cognitive representations or patterns of meaning are associated with work - for example, work as a source of pleasure, an obligation, or a right. The fourth topic brings together studies on the causes and consequences of the prolonged absence of work (Brief \& Nord, 1990; Feather, 1990; Warr, 1987), including analyses of coping strategies (e.g., in relation to the lack of meaning implicated by the absence of work).

The fifth topic, interdependent with the previous topics, involves understanding why work has very different meanings for different people, as occupations and cultures vary (Allende, Saez, Apodaka, Castañares, \& Ardanaz, 2003; Dakduk, González, \& Montilla, 2008; Drenth, 1991; England \& Harpaz, 1990; Gómez, 
2004; Gracia, Martín, Rodríguez, \& Peiró, 2001; Martínez, Soria, Cifre, \& Gumabu, 2001; MOW, 1987). This research seeks to identify patterns of meaning and to contextualize them. Finally, the last topic in this brief review includes systematic studies of social representations of work (Borges, 1996; Moliner, Rateau, \& Cohen-Scali, 2002; Suárez, Torregrosa, Bergère, \& Alvaro, 1998).

The axis of studies on the meaning of work is the most traditional in the field literature and tends to emphasize the cognitive dimensions of meaning (Rosso et al., 2010). A critical question left open by the studies in this axis, as identified by Pratt and Ashforth (2003), concerns the overlap between meaning at work and meaning in work. Pratt and Ashford argue that such a distinction is crucial to understanding the process of signification at work, and they and others set out to do this through the second axis, the meaningfulness of work.

\section{The Meaningfulness of Work}

Meaningfulness at work is related to the psychological mechanisms that allow individuals to consider their work as having the potential to be significant (Rosso et al., 2010). But what must be present in the work - or in the person - in order for the meaningfulness to be identified? What are the psychological mechanisms involved in the experience of meaningfulness at work? The studies gathered in this axis can help us find the answer.

The first of the studies are from Morin $(1996,1997,2002)$, an author whose influence can be seen in Brazilian studies (e.g., Morin, Tonelli, \& Pliopas, 2007; Tolfo \& Piccinini, 2007). Based on MOW (1987), the theoretical model proposed by Hackman and Oldham (1976), and the existential-phenomenological perspective (Weisskopf-Joelson, 1968), Morin proposed that the meaningfulness of work can be understood in terms of three components: significance (cognitive representation), orientation (direction, values, beliefs), and consistency between the self and work - the possibility of a person experiencing a sense of coherence between his or her meanings and personal orientations and the experience of performing work in specific conditions.

These three components of the meaningfulness of work combine in what Morin $(1996,1997,2002)$ calls the factors of the meaningful, classified into six categories. The work must 1) be efficient and produce a useful result, 2) provide pleasure in its execution, 3) allow the individual's autonomy, 4) be a source of satisfactory human relations, 5) keep the individual occupied, and 6) be morally acceptable.

Other authors have used similar concepts of consistency and authenticity to explain meaningfulness at work. For example, Ryan and Deci (2001) discussed the importance of consistency or alignment between one's behavior and perceptions of one's true self. In turn, Pratt and Ashforth (2003) suggested that meaningfulness is achieved when individuals experience a consistency between their personal identity and the activity they perform. Some of these authors have utilized concepts from identity theory (Stryker, 1987) and social identity theory (Tajfel, 1981) to construct a model in which the meaningful is a product of individuals' continuous management of the social roles that they perform and with which they identify (self-perceived or personal identity), on the one hand, and the commitments and requirements arising from their belonging to specific social/occupational groups (assigned or social identities), on the other.

In short, the axes of meaning and meaningfulness reflect a diversity of perspectives. The fact that they have been discussed separately does not mean that they are independent of each other, although there may be differences between them. Some authors have reported on both axes or admit the influence of both axes in their studies - for example, Morin $(1996,1997)$. In this research, we follow this direction and explore the meaning (both in meaning as such and in the meaningfulness sense) and tensions involved in artwork.

\section{METHOD}

We carried out our objective of identifying and describing the meaning and meaningfulness of work in the experience of the artist through in-depth interviews (Bernard \& Rian, 2009). We assume that meaning refers to cognitive representations that organize one's experience with work, whereas meaningfulness refers to the experience of consistency between self and work through the identification of characteristics of meaningfulness (Morin, 1996, 1997, 2002). In addition, we sought to identify tensions that the participants perceived in carrying out their work. The hypothesis we adopt in this study is that such tensions arise from the perception of a distance between the ideative aspects of work, present in the sense of meaningfulness, and contextual aspects, present in the artist's evaluation of his/her work conditions. 


\section{Participants, Procedures, and Data Collection Techniques}

The study included 26 artists distributed in three cultural sectors - plastic arts, performing arts, and literature - all located in the state of São Paulo. We obtained the sample by means of convenience, from a list of 100 names of artists collected through an extensive survey of websites, cultural organizations, associations, and other means that make available the names of artists. This survey was based on the criteria proposed by Throsby (2001a, 2001b) for determining who can be classified as an artist as well as which sectors can be considered artistic. According to Throsby, an artist is a person who has professional training, who devotes him - or herself fully to his or her artistic activity (to differentiate artists from those who engage in such activities as hobbies or leisure), who has produced a set of works (books, paintings, items, etc.), and who has gained during his or her career both peer and public recognition (not only in the narrow sense of awards and distinctions, but also social recognition as an artist). We contacted individuals who fulfilled these main criteria for inclusion in this study. When making the contacts, we explained the research objectives and the relevant operational details.

The artists who agreed to contribute to the study participated in individual interviews lasting about $90 \mathrm{~min}$. Each interview was guided by a script containing topics related to career, context or work environment, the representations or meaning of artwork, the meaningfulness of artwork (characteristics of meaningful work), and finally, perceived tensions in the conduct of the artwork. Each interview was recorded, transcribed, and later sent to the participant for approval and/or rectification. All information was processed in a way that preserves the anonymity of the respondents.

In terms of demographics, $70 \%$ of the participants were men; the average age was 45 years; and $34 \%$ of the participants were performing artists, $27 \%$ were plastic artists, and $39 \%$ were writers. The average experience in these activities was 23 years, and most participants had established careers consolidated in their area, in the sense of works already produced, specific training for the work performed, and integration in various art spaces. Therefore, our sample consisted of experienced artists.

\section{Procedures for Data Analysis}

We analyzed the data with the aid of specific software for qualitative analysis based on procedures of empirical reduction through thematic categorization (Gibbs, 2007). First, we created a database with the content of the interviews. Next, we conducted an overall assessment of its contents, with a view to familiarizing ourselves with the material. Then we conducted the classification itself, guided by three preanalytical categories: the meaningfulness of work, the meaning of work, and the tensions perceived by the artist in the exercise of his or her work.

From the detailed and comparative analysis of the content, we created subcategories (based on their emergence from the data) and determined the frequencies of their corresponding themes. We created subcategories for the meaningfulness of work by identifying issues with distinct semantic nuclei that were related to the meaningfulness of work. That is, we evaluated the material with a view to reducing the data to systematic sets represented by cores of meaningfulness of work - as the process is often operationalized in routines of qualitative categorization (Auerbach \& Silverstein, 2003; Ryan \& Deci, 2001). We used the same principle for the subcategories of tensions at work. For the subcategories of the meaning of work, we adopted a categorization process in which data are reduced to more central cores based on "anchors" of meaning that have great potential as organizers of the subjects' narratives. In social psychology, this is known as the core technique of representations or social meanings (Seca, 2001).

The last stage of analysis consisted of an analytical induction process (through an adaptation of the strategies suggested by King, Keohane, \& Verba, 1994) in which we used our theoretical framework and broader contextual information to propose explanations for the contents of the categories and subcategories we had identified. We proposed interpretations for the categories of meaning, meaningfulness, and tensions in artistic work.

\section{RESULTS AND DISCUSSION}

The results are organized into three parts. In the first, we discuss the category of meaningfulness at work and its subcategories; in the second, we discuss the category of meaning; and in the third, we discuss the tensions participants perceived in conducting their work. 


\section{The Meaningfulness of Artistic Work}

Table 1 shows the subcategories of meaningfulness in work as perceived by the artists we interviewed. The first subcategory contains topics concerning the impact of the artwork. The participants in the study perceive that their work in the arts allows them to contribute to other individuals' aesthetic processing as well as that of the society, in the sense that their work evokes aesthetic sensitivity and reflection. This finding coincides with a finding indicated in the Morin model $(1996,1997,2002)$, for which the social value of work is a source of meaningfulness.

TABLE 1. Subcategories of Meaningfulness in Artistic Work

\begin{tabular}{lcccc}
\hline & \multicolumn{3}{c}{$\begin{array}{c}\text { Frequency of citation of the themes that make up the } \\
\text { subcategory }\end{array}$} \\
\cline { 2 - 4 } Subcategories & $\begin{array}{c}\text { Performing arts } \\
(\mathrm{n}=9)\end{array}$ & $\begin{array}{c}\text { Plastic arts } \\
(\mathrm{n}=7)\end{array}$ & $\begin{array}{c}\text { Literature } \\
(\mathrm{n}=10)\end{array}$ & Total (N=26) \\
Work impacts & 4 & 4 & 5 & 13 \\
Task variation, novelty, challenge, and risk & 4 & 3 & 3 & 10 \\
Quality, consistency of work/performance & 4 & 4 & 1 & 9 \\
Recognition & 5 & 2 & 1 & 8 \\
Authorship, creation & 3 & 2 & 2 & 7 \\
Autonomy & 3 & 1 & 2 & 6 \\
Pleasure and satisfaction & 0 & 4 & 0 & 4 \\
Learning and growth & 1 & 1 & 1 & 3 \\
Financially supported by own work & 1 & 2 & 0 & 3 \\
Relationships & 2 & 0 & 0 & 2 \\
Total & 27 & 23 & 15 & 65
\end{tabular}

Note. ${ }^{a}$ Repeated mentions of the same subject within the same interview are disregarded in this count.

The second subcategory concerns the activity itself, its content - which the participants perceived as challenging, constantly changing, and rich in novelty. That is, artists do not identify "routineness" in their work in the sense of tasks that follow specific procedures and lead to predictable results, all the same. Paradoxically, this dynamic of uncertainty seems to have motivational effects for many of the interviewed artists, as not knowing a priori the end result of their work seems to trigger creativity and innovation. This interpretation is convergent with empirical findings on artwork in the field literature that suggest that uncertainty about the outcome of a performance opens up possibilities for imagination and surprise (e.g., Menger, 2002, 2009). This apparent paradox may be a function of the specific group of research participants, particularly considering their experience level (how long they have worked) in the arts.

The third subcategory, quality and consistency of artwork, is another source of meaningfulness. Seeing themselves as professionals, artists believe that they should improve their performance as much as possible. A concern with training and continuous development was evident in the interviewees' narratives. Artists use the quality of their work as a means of self-regulation to monitor their progress and maturation. This seems to make sense because, unlike other professionals, they have no immediate boss or manager to provide feedback on the quality of their work. In this way, the senior artists who were invited to be included in our sample developed unique capacities for self-observation and analysis.

However, recognition is a special issue in the case of artists. The recognition comes from the public, whose relationship with the artist can be distal or proximal; from peers, who, as pointed out by theories such as the psychodynamics of work (Dejours, 2008), provide an aesthetic judgment of the artwork; and from others such as the market, art dealers, agents, and the state.

The next two subcategories, authorship/creation and autonomy, are intrinsically linked. On the one hand, artists believe that their work is meaningful when they feel they are exercising their agency (Bandura, 1986), i.e., that they have mastery and control. On the other hand, for artists, the possibility of authorship should be accompanied by autonomy. This is consistent with representations of the arts as sectors governed by the logic of craftsmanship (Menger, 2002; Sennett, 2009). According to this logic, work is organized in an artisanal manner, something like a "pre-Taylorist" work division and organization - at least if we consider the sectors in which the participants of this study work: the performing and visual arts and literature. At this point, we can hypothesize that given the intensification of mass production in the arts, the industries and types of work described in the present study may influence this representation of artwork as creation and of the artist 
as an autonomous subject. The intensified mass production might also, we may hypothesize, bring artists to experience tensions in carrying out their work, as described later in this article.

We conclude this section with some comments about subcategories in Table 1 whose themes were less frequently cited - specifically, the last two. It is interesting to note that an instrumental topic relating an individual and his or her work, namely, financial survival, appeared in the interviews less frequently than other topics. Obviously, surviving at one's own work - particularly in the arts, a sector in which the possibilities of gain are uncertain (Caves, 2000) - is a legitimate source for a sense of meaningfulness. However, financial issues do not appear at the top of the hierarchy of values through which artists evaluate their work. Perhaps this becomes more understandable in light of representations about the arts and their relationship with the economic universe (Chateau, 2008; Menger, 2009). For example, the purpose of art is not primarily commercial, but rather aesthetic, educational, and critical. This is not to say that financial issues are not important to professional artists. Many of the interviewees survive through their artistic work, and to do so they need to be paid. However, the artists seem to use financial aspects least frequently than the other subcategories for finding meaning/meaningfulness (maybe this can be related to social desirability).

Finally, the topic of professional relationships also appeared with low frequency, perhaps due to the more introspective nature of the activities performed in the fields of fine arts and literature - which is not to say, however, that artists are imagined to be solitary individuals. But in principle, the meaningfulness of their work seems to do more with their work and activities than the level of their relationships with peers. Next, we will analyze the meaning of work category.

\section{The Meaning of Artistic Work}

As described in the discussion of our data analysis procedures, we assessed the meaning of work category using a data reduction process on core representations or meanings. In particular, we focused on three cores, which we now detail.

The first core or subcategory is the representation of work as flow and pleasure. There is, so to speak, a hedonic conception of work such that it must be intrinsically motivating. This is illustrated by the fact that many respondents negatively evaluated work in other sectors of the economy, which they saw as routine and devoid of intrinsic motivational qualities. This way of judging the noncultural (or "traditional") sectors is also found in other studies on artwork and artists (e.g., Chiapello, 1998).

The concept of flow is discussed in the (positive) psychology literature by Csikszentmihalyi (1991). In the flow experience, individuals experience a feeling of deep integration with the object of their activity. The respondents in this study suggested the presence of such a feeling in their experience - for instance, when they described their intense emotional involvement in the representation of a character or while painting a screen or writing a book. These are activities with a high level of intellectual and emotional demands, and artists feel that they have the requisite skills in proper proportions for performing them. When they engage in these activities, artists "forget" themselves, following the flow of thought, body, and emotions. The experience of feeling in flow would then be the basis for the pleasure and satisfaction they experience at the end of each activity.

The second core of the meaning of work that emerged from the interviews concerns the representation of work as a vocation in the sense of Wrzesniewski et al. (1997). An orientation toward work as a vocation makes it a "mission," or, in the language of the artists, a "need." This orientation is also related to the pursuit of transcendence, as defined by Lips-Wiersma (2002): a dedication to goals that go beyond one's own self and one's most immediate interests (career advancement, for example). This is, in short, an orientation to work that differentiates it from the idea of a (traditional) job and instrumental characteristics normally attached to paying jobs. In fact, as we shall see in the next section, work as a vocation seems to fit better with the idea of a profession than with that of a job - particularly because, in the world of the arts, activities are project-oriented, that is, done without a formal contract (Menger, 2002; Segnini, 2009).

Finally, the third representation or core meaning of work is related to its creative potential, aesthetic transformation, and subjective mobilization. Through their artistic activity, the respondents seek to achieve high values in terms of certain aesthetic, technical, and social standards (also a form of transcendence). Seen from this perspective, artwork is a source of self-expression for artists, their "language" for communication with the world. Using the model proposed by Pratt and Ashforth (2003), we can say that the meaning of 
artwork is closely linked to the artist's identity. This is a point of possible complementarity between meaning (the first axis) and meaningfulness (the second axis) of work. In this context, it is understandable that tensions emerge when the artist does not experience authenticity and consistency between the representation of him or herself as an artist (the artist's identity) and the work and activity that the artist actually performs - which may be, for example, a derivative of interlocking conflicts between art and business. We will now analyze this and other consequent tensions.

\section{Tensions in the Realization of Artistic Work}

Table 2 presents subcategories whose themes refer to tensions in artists' work. We consider tensions to be the result of a perceived gap between meaningfulness and meaning; these can manifest either as dichotomies (e.g., the subcategory "art and business") or as points of concern or difficulties (e.g., the subcategory "the value of art and the artist"). Due to space constraints, we will only discuss the most potentially suggestive themes in our analysis.

TABLE 2. Subcategories of Tensions Perceived in the Realization of Artistic Work

\begin{tabular}{|c|c|c|c|c|}
\hline \multirow{2}{*}{ Subcategories } & \multicolumn{3}{|c|}{$\begin{array}{l}\text { Frequency of citation of the themes that make up the } \\
\text { subcategory }\end{array}$} & \multirow{2}{*}{$\begin{array}{c}\text { Total } \\
(\mathrm{N}=26)\end{array}$} \\
\hline & $\begin{array}{l}\text { Performing arts } \\
\qquad(\mathrm{n}=9)\end{array}$ & $\begin{array}{l}\text { Plastic arts } \\
\qquad(n=7)\end{array}$ & $\begin{array}{l}\text { Literature } \\
\qquad(n=10)\end{array}$ & \\
\hline The value of art and the artist & 3 & 6 & 3 & 12 \\
\hline The activity itself & 6 & 2 & 2 & 10 \\
\hline Insecurity and financial instability & 2 & 3 & 3 & 8 \\
\hline Professional and amateur & 5 & 2 & 0 & 7 \\
\hline Art and business & 2 & 3 & 2 & 7 \\
\hline Quality and price & 1 & 3 & 0 & 4 \\
\hline Peer relationships & 1 & 1 & 0 & 2 \\
\hline Maker and creation & 1 & 1 & 0 & 2 \\
\hline Pleasure and obligation & 0 & 2 & 0 & 2 \\
\hline Total & 21 & 23 & 10 & 54 \\
\hline
\end{tabular}

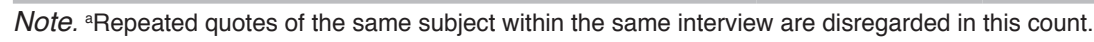

The first subcategory of tensions in Table 2, the value of art and the artist, concerns the perception that art and artists do not receive their proper value in Brazil. This perception is based on conditions such as low demand for the arts, the occasional replacement of professional artists by people with no artistic training, pressures to reduce costs that have a direct impact on the quality of the art, and the low level of the arts' attractiveness to organizations that could invest more in partnerships with artists. In short, these conditions point to a low social value assigned to artists' activity, in contrast to what artists believe they give to society in return through their artistic activity.

The second subcategory concerns the actual execution of artwork. This category highlights ergonomic aspects of the activity; excessive workloads due to several projects being executed at the same time, tight deadlines, and the complexity of the tasks; physical conditions such as the use of toxic materials (plastic arts) or scenarios in very different environments, some with high risks (performing arts); and the high level of care and emotional regulation that certain activities require. This subcategory is associated with health parameters, both physical and mental, that involve unpleasant experiences and suffering and that demand coping strategies that vary according to experience, the individual's characteristics, and the activities (for an example of research on suffering in artwork and coping, see Macêdo, 2010).

Another subcategory of tensions concerns the binomial professional/amateur. The respondent artists have a representation of their work as professionally oriented. They define a professional as one who manages to combine talent and technique, passion and discipline, inspiration and execution. Additionally, professional artists have specific training, based on attendance at schools, self-education, or experience. However, professional artists must live with other workers who, according to the respondents, do not always have professional backgrounds. This is a source of tension, derived from the porosity of the boundaries between art and nonart, leisure and work, improvisation and planning, professional and amateur. Perhaps this will help us better understand the complaint of artists regarding the low level of appreciation of their work as well as another tension presented in Table 2, quality versus price. 
The next subcategory of tensions derives from conflicts between art and business. As we saw in the previous section, there is a representation of the arts in which they remain apart from (sometimes, in an opposite relation to) the economic universe. The arts correspond to the field of human experience that deals with intangible values, not necessarily economic values. However, as theorists of the Frankfurt School (e.g., Adorno \& Horkheimer, 1985), for example, have shown, modernity has generated processes for capturing of the arts by capitalism. Recently, the emergence of creative industries (Hartley, 2005) has given another impetus to the intertwining of art and business, with art understood mainly as a source of capital generation and jobs.

From the artists' point of view, this entanglement is not without conflicts and compromises. For example, they pointed out that an overly commercial orientation can destroy the value of art, generate anything but art (cultural consumption of the masses, for example), and block creativity and an independent spirit, which are both fundamental for creation. At the same time, as another set of tensions - quality versus price indicates, artists live with the dilemma of having to attach figures to something intangible: the value of their artwork. Yet when the artwork is given its price and is sold, artists feel that their work has met the criteria of professionalism. In this sense, economics functions as a transitional contract for artists, allowing them to survive financially through their work and to consolidate their professional identity.

Finally, we comment briefly on the last two subcategories of tensions: those between maker and creation and between pleasure and obligation. The first concerns the relationship between artists and their work. There are cases in which artists are at the service of their work - for example, when the "character" dictates what the artist must do, or when a work is made to order and according to specifications given in advance and by others (clients). In other instances, it is the work that is at the artist's service - for example, when an artist's personality "brands" any character to be represented. As a consequence, there is an overlap between artists and their work, which makes their separation difficult and problematic.

The second final subcategory of tensions, between pleasure and obligation, concerns a discrepancy between the ideational elements of artwork (meaningfulness) and the practical aspects of its exercise. For example, an artist who does not want, at a certain time, to paint or write but who has entered into commitments (with clients, for instance) will have to work anyway. This mismatch between desire and obligation may not be a characteristic unique to workers in the arts. However, in the case of the artist, the mismatch seems critical, given the close relationship between artists' psychological states and their performance. For the artists surveyed, work presupposes pleasure and affective involvement at levels that are ideally the same, so that the absence of a lasting state of pleasure and affective involvement may be interpreted as frustrating and may therefore demand personal strategies for coping. As can be seen from our findings, there seems to be an intimate relationship between tensions in artwork and perceptions of its meaningfulness and meaning. The analysis of this relationship can bring new insights to the research on meaningfulness and meaning in work. We close this article with some suggestions for future research in this direction.

\section{CONCLUSIONS}

In addition to proposing suggestions for future research, we also want to integrate the issues discussed throughout this article with a recasting of its initial objective, an analysis of the meaningfulness and meaning of artwork, to reflect on similarities and differences between these and the tensions arising from the distance the artist perceives between them. We hope ultimately to instigate other researchers to explore this theme in occupational psychology.

The subcategories of meaningfulness identified in the work experience of our respondents are in line with categories of meaningfulness proposed in the psychological literature by Morin (1996, 1997, 2002), and this seems to suggest that these characteristics are extensible to a wide range of activities. What seems to distinguish artists is their interpretation of the tensions that arise in the concrete performing of their work. This means that the content of the activity can exert an indirect influence on the factors of meaningfulness.

Comparing the categories of meaningfulness and meaning as discussed in the previous sections, we see that there can be interdependencies between them. For example, when artists represent their work as a flow, they probably become more sensitive to situations with routine requirements and situations in which they have to carry out activities under more intense commercial pressures. Similarly, conceiving their work as a vocation brings a high level of emotional identification with the activity - which, in turn, is reflected in a high commitment to their profession/career and a greater ability to withstand the activity's exacting demands as well 
as the difficulties of continuing as a professional artist in an uncertain market. Similarly, the representation of artwork as creation makes it an intrinsically motivating activity, because the artist can exercise his or her sense of agency and mastery. New research could develop explanatory models about what kinds of interrelations exist between meaningfulness and meaning factors, exploring the role of variables that precede and are predicted by them.

It is also useful to reflect on empirical differences between the categories of meaningfulness and meaning. We can, for example, hypothesize that meaningfulness involves more natural, personal, and constitutive aspects of the relationship between a person and his or her work, while meaning involves broader aspects, originating in specific sociohistorical productions as well as reflecting inherited conceptions via socialization processes - both primary (family, school) and professional (relating to work experience). In addition, perhaps the subcategories of meaningfulness presented in Table 1 refer to more "subjective" psychological constructs (in the sense of constituting the "psychological subject"), such as those related to the construction of selfconcept and own self, and to affects and ideals.

We can also suggest, in a purely hypothetical way, that meaningfulness at work concerns the evaluative dimension of the meaning of the work in the broad sense and is thus influenced by values and beliefs. This raises another possibility: that meaningfulness (concerning the natural elements of the experience of the individual with his or her work and the consistency between self and work/employment) encourages greater (affective) engagement with work, minimizing or mitigating any possible negative work conditions related to the exercise of a particular job or occupation. For example, despite the various tensions we have discussed, none of the artists suggested the possibility of abandoning their activity in the arts, but rather the opposite. The decision of remain in the art sector can also be explained by differences at the level of subjective perception between a job (one's employment) and the work, or between work and a particular occupation. As we hypothesized in the theoretical review section, distinctions between job and work with respect to the construction of meaningfulness/meaning constitute an important topic. Finally, we cannot fail to mention that other factors of a psychosocial, ideological, or economic nature may help explain this engagement of the artists with their artwork. However, we can still sustain the hypothesis that the perception of sense in work can be a predictor of the level of (affective) involvement with the work.

This opens up room for thinking about how people who perform even the most insipid work that is devoid of expressive content (meaning) can find pleasure, meaningfulness, and purpose in their work, and also for being more cautious about generalizing certain abstract patterns of the meaning of work that do not necessarily resonate in the experience of people in specific situations and conditions. Such generalizations are often based on cognitive structures that are effectively not shared by all social or occupational groups, so that work psychology research itself can fall into a trap by taking work as a dangerously homogeneous category.

We should end this article with reference to the context of its realization: artists from the state of São Paulo. It should be noted that due to the large differences between Brazilian regions, apart from the methodological scope adopted, it is impossible to extrapolate characteristics of the sectors and the artistic-cultural workers from Sao Paulo to the rest of the country, so the study reported here serves only as a starting point.

\section{REFERENCES}

Adorno, T. W., \& Horkheimer, M. (1985). Dialética do esclarecimento. Rio de Janeiro: Jorge Zahar.

Allende, J. C., Saez, M. V., Apodaka, E., Castañares, I. U., \& Ardanaz, E. R. (2003). Nuevas prácticas de trabajo, representaciones sociales del trabajo e identidad social en la sociedad postindustrial. Revista de Psicología Social Aplicada, 13(2), 79-123.

Auerbach, C. F., \& Silverstein, L. B. (2003). Qualitative dada: an introduction to coding and analysis. New York: New York University Press.

Bandura, A. (1986). Social foundations of thought and action. New Jersey: Prentice-Hall.

Bernard, H. R., \& Rian, G. W. (2009). Analyzing qualitative dada. Thousand Oaks: Sage.

Borges, L. O. (1996). A representação social do trabalho. Estudos de Psicologia, 1(1), 7-25.

Borges, L. O. (1997). Os atributos do significado do trabalho. Psicologia: Teoria e Pesquisa, 13, 211-220.

Brief, A. P., \& Nord, W. R. (Eds.). (1990). Meanings of occupational work. Lexington, MA: Lexington Books. 
Buchholz, R. A. (1977). The belief structure of managers relative to work concepts measured by a factor model. Personnel Psychology, 30(4), 567-587. doi:10.1111/j.1744-6570.1977.tb02328.x

Caves, R. (2000). Crative industries. Harvard: Harvard University Press.

Chateau, D. (2008). Qu'est-ce qu'un artiste? Rennes: Presses Universitaires de Rennes.

Chiapello, E. (1998). Artistes versus managers. Paris: Métailié.

Csikszentmihalyi, M. (1991). Flow. New York: HarperCollins.

Dakduk, S., González, A., \& Montilla, V. (2008). Relación de variables sociodemográficas, psicológicas y la condición laboral con el significado del trabajo. Revista Interamericana de Psicología, 42(2), 390-401.

Dejours, C. (2008). Travail, usure mentale. Paris: Bayard.

Drenth, P. J. D. (1991). Work meanings: a conceptual, semantic and developmental approach. European Work and Organizational Psychologist, 1(2), 125-133. doi:10.1080/09602009108408517

Dubin, R. (1956). Industrial Workers' worlds. Social Problems, 3, 131-142.

England, G. W., \& Harpaz, I. (1990). How working is defined. Journal of organizational behavior, 11(4), 253-266.

Feather, N. (1990). The psychological impact of unemployment. New York: Springer.

Gibbs, G. (2007). Analysing qualitative data. Thousand Oaks: Sage.

Gonzales, J. P., \& Vilela, L. D. (2005). La centralidad del trabajo. Londres: Lulu.

Gómez, E. S. (2004). Concepciones del trabajo: de las ambigüedades medievales a las paradojas actuales. Cuadernos de relaciones laborales, 22(1), 37-65.

Gracia, F. J., Martín, P., Rodríguez, I., \& Peiró, J. M. (2001). Cambios en los componentes del significado del trabajo durante los primeros años de empleo. Anales de Psicología, 17(2), 201-217.

Hackman, J. R., \& Oldham, G. R. (1976). Motivation thorough the design of work: Test of a theory. Organizational Behavior and Human Performance, 16, 250-279. doi:10.1016/0030-5073(76)90016-7

Harpaz, I., \& Fu, X. (1997). Work centrality in Germany, Israel, Japan, and the United States. Cross-Cultural Research, 31(3), 171200. doi:10.1177/106939719703100301

Hartley, J. (2005). Creative industries. Londres: Blackwell.

Kanungo, R. N. (1982). Measurement of job and work involvement. Journal of Applied Psychology, 67(3), 341-349.

Kaplan, H. R., \& Tausky, C. (1974). The meaning of work among the hard-core unemployed. The Pacific Sociological Review, 17(2), 185-198.

King, G., Keohane, R. O., \& Verba, S. (1994). Designing social inquiry. Princeton: Princeton University Press.

Lips-Wiersma (2002). Analysing the career concerns of spiritually oriented people: Lessons for contemporary organizations. Career Development International, 7, 385-397. doi:10.1007/s10551-009-0118-9

Lips-Wiersma, M., \& Morris, L. (2009). Discriminating between meaningful work and the management of meaning. Journal of Business Ethics, 88, 491-511.

Macêdo, K. B. (Org.). (2010). O trabalho de quem faz arte e diverte os outros. Goiânia: Editora da PUC-Goiás.

Martínez, I., Soria, M. S., Cifre, E., \& Gumabu, S. L. (2001). Patrones de significado de trabajo, características del puesto y bienestar psicológico en trabajadores de producción. Revista de Psicología, 23(1), 93-112.

Meaning of Work Research Team (MOW). (1987). The meaning of working. San Diego, CA: Academic Press.

Menger, P. M. (2002). Portrait de l'artiste en travailleur. Paris: Seuil.

Menger, P. M. (2009). Le travail createur. Paris: Gallimard.

Moliner, P., Rateau, P., \& Cohen-Scali, V. (2002). Les représentations sociales. Rennes: PUR.

Morin, E. (1996). L'efficacité organisationnelle et sens du travail. In T. Pauchaunt (Ed.). La quête du sens (pp. 257-286). Quebec: Éditions de l'organisation.

Morin, E. (1997). Le sens du travail pour des gestionnaires francophones. Revue Psychologie du Travail e des Organizations, 3(2), 26-45.

Morin, E. (2002). Os sentidos do trabalho. In T. Wood (Ed.). Gestão empresarial (pp. 13-34). São Paulo: Atlas. 
Morin, E., Tonelli, M. J., \& Pliopas, A. L. V. (2007). O trabalho e seus sentidos. Psicologia \& Sociedade, 19(Edição Especial 1), 47-56.

Pratt, M. G., \& Ashforth, B. E. (2003). Fostering meaningfulness in working and at work. In K. S. Cameron, J. E. Dutton, \& R. E. Quinn (Eds.). Positive organizational scholarship (pp. 309-327). San Francisco: Berrett-Koehler Publishers.

Ros, M., Schwartz, S. H., \& Surkiss, S. (1999). Basic individual values, work values, and the meaning of work. Applied Psychology, 48, 49-71. doi:10.1111/j.1464-0597.1999.tb00048.x

Rosso, B., Dekas, K., \& Wrzesniewski, A. (2010). On the meaning of work: A theoretical integration and review. Research in Organizational Behavior, 30, 91-127. doi:10.1016/j.riob.2010.09.001

Ryan, R. M., \& Deci, E. L. (2001). To be happy or to be self-fulfilled: A review of research on hedonic and eudaimonic well-being. Annual Review of Psychology, 52, 141-166.

Salanova, M., Gracia, F. J., \& Peiró, J. M. (1996). Significado del trabajo y valores laborales. In J. M. Peiró, \& F. Prieto (Eds.). Tratado de psicología del trabajo (pp.35-63). Barcelona: Sintesis.

Seca, J. M. (2001). Les représentations sociales. Paris: Armand Colin.

Segnini, L. R. P. (2009). Políticas públicas e mercado de trabalho no campo da cultura. In M. de P. Leite, \& A. M. C. Araújo (Eds.). O trabalho reconfigurado (pp. 95-122). São Paulo: Annablume.

Sennett, R. (2009). The craftsman. Yale: Yale University Press.

Stryker, S. (1987). Identity theory: developments and extensions. In K. Yardley, \& T. Honess (Eds.). Self and identity: psychosocial perspectives (pp.89-104). New York: John Wiley.

Suárez, E. C., Torregrosa, J. R., Bergère, J., \& Alvaro, J. L. (1998). Los significados del trabajo: un alálisis lexicográfico y discursivo. Sociología del trabajo, 33, 51-70.

Super, D. E., \& Sverko, B. (Eds.). (1995). Life roles, values, and careers. San Francisco: Jossey-Bass.

Tajfel, H. (1981). Human groups and social categories. Cambridge: Cambridge University Press.

Throsby, D. (2001a). Economics and Culture. Cambridge: Cambridge University Press.

Throsby, D. (2001b). Defining the artistic workforce: The Australian experience. Poetics, 28, 255-271. doi:10.1016/S0304$422 \times(01) 80003-6$

Tolfo, S. R., Coutinho, M. C., Baasch, D., \& Cugnier, J. S. (2011). Sentidos y significados del trabajo: Un análisis en base a diferentes perspectivas teórico-epistemológicas en Psicología. Universitas Psychologica, 10(1), 175-188.

Tolfo, S. da R., \& Piccinini, V. (2007). Sentidos e significados do trabalho: explorando conceitos, variáveis e estudos empíricos brasileiros. Psicologia \& Sociedade, 19, 38-46. doi:10.1590/S0102-71822007000400007

Tomás, E. A. (1998). La centralidad del trabajo en el proceso de construcción de la identidad de los jóvenes. Psicothema, 10(1), 153-165.

Warr, P. (1987). Work, unemployment and mental health. Oxford: Clarendon Press.

Weisskopf-Joelson, E. (1968). Meaning as an integrating factor. In C. Bühler, \& F. Massarik (Eds.). The course of human life (pp. 359-382). Oxford: Springer.

Wrzesniewski, A., McCauley, C., Rozin, P., \& Schwartz, B. (1997). Jobs, careers, and callings: People's relations to their Work. Journal of Research in Personality, 31, 21-33. doi:10.1006/jrpe.1997.2162 